\title{
High-Resolution Episcopic Microscopy (HREM): Looking Back on 13 Years of Successful Generation of Digital Volume Data of Organic Material for 3D Visualisation and 3D Display
}

\author{
Stefan H. Geyer ${ }^{(\mathbb{B}}$ and Wolfgang J. Weninger *(D) \\ Division of Anatomy \& MIC, Medical University of Vienna, 1090 Vienna, Austria; \\ stefan.geyer@meduniwien.ac.at \\ * Correspondence: wolfgang.weninger@meduniwien.ac.at; Tel.: +43-1-40160-37560
}

Received: 18 August 2019; Accepted: 9 September 2019; Published: 12 September 2019

\begin{abstract}
High-resolution episcopic microscopy (HREM) is an imaging technique that permits the simple and rapid generation of three-dimensional (3D) digital volume data of histologically embedded and physically sectioned specimens. The data can be immediately used for high-detail 3D analysis of a broad variety of organic materials with all modern methods of 3D visualisation and display. Since its first description in 2006, HREM has been adopted as a method for exploring organic specimens in many fields of science, and it has recruited a slowly but steadily growing user community. This review aims to briefly introduce the basic principles of HREM data generation and to provide an overview of scientific publications that have been published in the last 13 years involving HREM imaging. The studies to which we refer describe technical details and specimen-specific protocols, and provide examples of the successful use of HREM in biological, biomedical and medical research. Finally, the limitations, potentials and anticipated further improvements are briefly outlined.
\end{abstract}

Keywords: imaging; 3D; high-resolution episcopic microscopy; episcopic; phenotyping; HREM

\section{Introduction}

Imaging plays a central role in all areas of modern science and is one of the most expanding fields of biomedical research. Therefore, a plethora of highly sophisticated imaging methods spanning from ground-penetrating radar to Brillouin microscopy were developed in the last century [1-3].

In particular, the life sciences had a massive benefit from the availability of novel imaging modalities designed for 3D visualisation of living humans and animals, harvested embryos and tissue samples. Techniques such as single-photon emission computed tomography (SPECT) and positron emission tomography (PET), micro-computed topography $(\mu \mathrm{CT})$ and optical coherence tomography (OCT) are already used as routine tools for the diagnosis of pathologies in the clinical routine [4-9]. Others, such as micromagnetic resonance tomography ( $\mu \mathrm{MRI}$ ), atomic force microscopy (AFM) and optical projection tomography (OPT), are still restricted to the scientific analysis and characterisation of biological samples [10-16]. Their focus rests on the interpretations of the three-dimensional (3D) arrangement of organs, tissues, cells and molecules in healthy and diseased organisms, which is the basis for understanding the genetic, epigenetic and functional aspects of developmental processes, the genesis of pathologies and the effect of strategies to treat diseases.

Each imaging method has unique advantages for a small field of applications. But due to technical constraints, most are restricted to highly specific research fields and a narrow selection of specimen types. A method that is highly potent, especially in structural 3D visualisation of embryos of biomedical models and biopsy material, is high resolution episcopic microscopy (HREM). 
HREM [17] is an episcopic imaging method which generates a series of inherently aligned digital images of histologically processed and embedded specimens. The images are virtually stacked to be analysed by scrolling through the original or virtual resections and to lend themselves to volume rendering or segmentation and surface rendering. Thus, HREM is in line with other episcopic imaging techniques, such as serial block-face scanning electron microscopy (SBFSEM) [18], serial reconstruction technique [19-21], Epi-3D [22], surface imaging microscopy [23,24], imaging cryomicrotome [25], serial block-face imaging [26] and episcopic fluorescent image capturing (EFIC) [27], although it is optimised for a low microscopic level of resolution.

In a nutshell, materials are harvested and processed as for traditional histology. During dehydration, they are stained with eosin red mixtures, and resin (JB4) dyed with eosin or eosin/acridine orange is used for infiltration and as an embedding material. The resulting resin blocks are sectioned on a microtome, while digital images of subsequently exposed block surfaces are captured in fluorescence-mode using yellow fluorescent protein (YFP) (excitation 500/20 nm, emission 535/30 nm) or green fluorescent protein (GFP) (excitation 470/40, emission 525/50) filter sets for visualising eosin-contrasted structures. Cells and tissues specifically stained with LacZ or NBT/BCIP (nitro-blue tetrazolium and 5-bromo-4-chloro-3'-indolyphosphate) appear heavily contrasted when also using a Texas Red filter system as shown in Figure 1. Several protocol variations optimised for various materials are already published and extensively discussed [28-32].

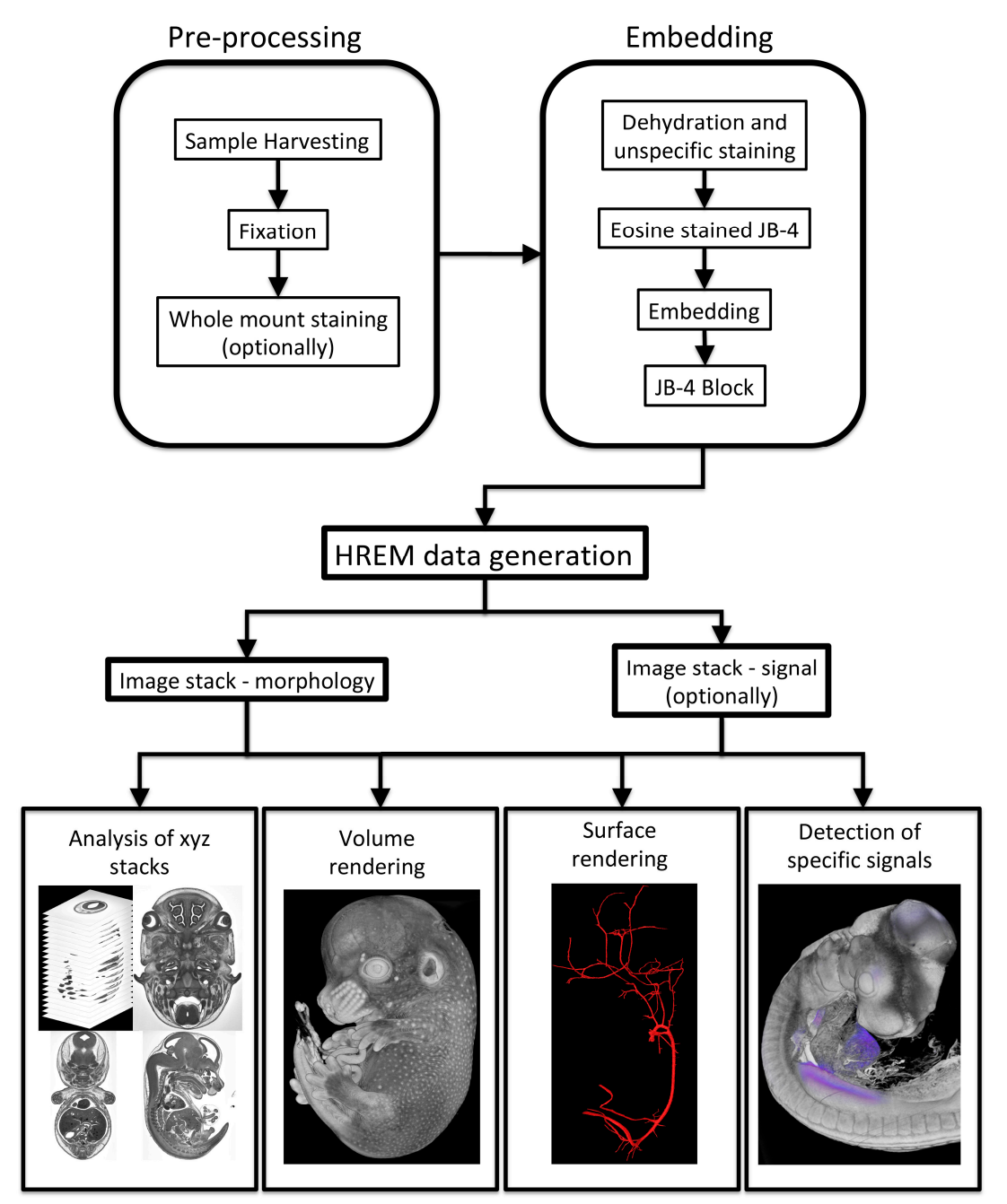

Figure 1. Workflow. The flow chart briefly summarizes the steps of the HREM-workflow from sample harvesting to $3 \mathrm{D}$ visualisation and data analysis. 
HREM data typically have a voxel size of $2 \times 2 \times 2 \mu \mathrm{m}^{3}$ and are created from specimens with a volume of $6 \times 6 \times 6 \mathrm{~mm}^{3}$, although larger and smaller samples and higher or lower resolutions are possible. Data contrasts fit for identifying cells and nuclei, nerve fibres, capillaries and collagen bundles in the context of overall morphology and tissue architecture. Data generation varies according to specimen size, but it takes approximately $4-5 \mathrm{~h}$ for data comprised of 2000 single section images. Since numerous publications comprehensively describe the method [33-36] and ready-to-go HREM apparatuses are already commercially available (OHREM, Indigo Scientific Ltd., Baldock, England), this paper will not provide protocols or technical descriptions, but will focus on discussing published scientific results and potential applications.

\section{Applications of HREM}

HREM has been employed in various areas of the life sciences and for visualising a number of different organic materials. Its chief domains of application are phenotyping of embryos of biomedical model organisms and structural analysis of human biopsy material. Besides those, there are a number of unconventional applications.

\subsection{HREM in Embryo Research}

HREM was used for analysing whole embryos or embryonic organs and tissues of various species, including humans. However, the highest impact in this field was gained from phenotyping mouse embryos and from the selection of HREM as the tool for phenotyping mouse mutants harvested at embryonic day (E) 14.5 in the Deciphering the Mechanisms of Developmental Disorders (DMDD) program.

\subsubsection{Mouse Embryos}

Moderate breeding costs, short generation times and the existence of sophisticated molecular tools to manipulate the mouse genome facilitate efficient engineering of mutant mouse lines by random or targeted disruption of specific genes. Due to the conservation of basic developmental mechanisms and gene function, such lines are then used for studying normal mammalian gene function and the genetic components of diseases.

Identifying morphological defects of mouse embryos of genetically engineered mouse lines is an important step to characterise the function of the disrupted gene during embryo development and to define its role in the genesis of hereditary diseases and malformations. HREM was developed to permit the production of 3D volume data of whole E14.5 mouse embryos in a resolution and quality to fit for a holistic qualitative and quantitative analysis of embryo morphology, organ, blood vessel and nerve topology and tissue architecture as shown in Figure 2. In the scope of DMDD [37], which was linked with the International Mouse Phenotyping Consortium (IMPC), HREM was employed to build a virtual resource of fully annotated phenotype data of over 200 normal and over 500 mutant mouse embryos harvested at E14.5 stemming from 87 individual single knock-out or knock-down lines producing lethal or subvital homozygous offspring. 


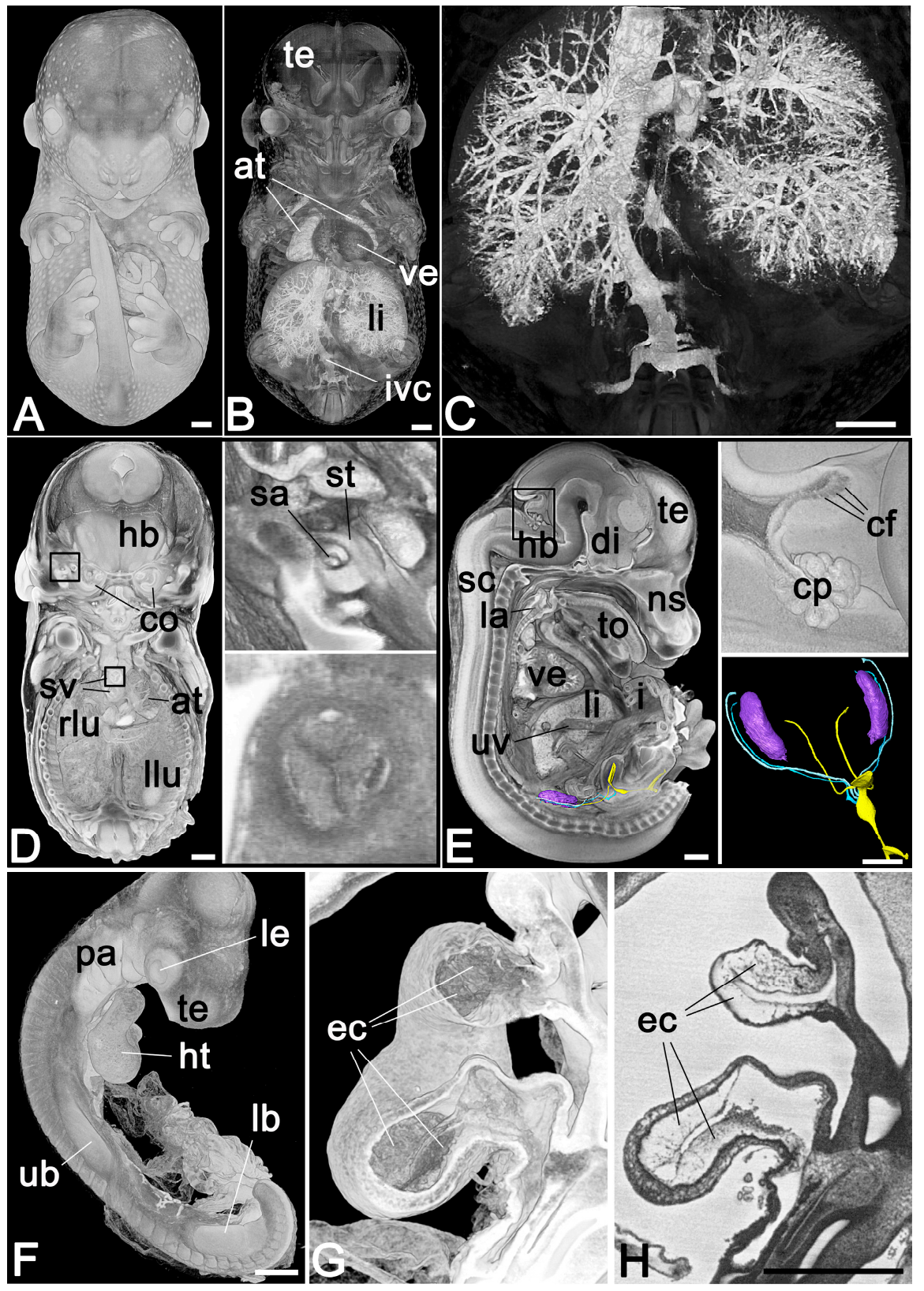

Figure 2. 3D visualisation of embryo material. (A-E). Embryos harvested at embryonic day 14.5 in the scope of the Deciphering the Mechanisms of Developmental Disorders (DMDD) project. Opaque and semitransparent volume models from ventral view (A-D). Note the intrinsic contrast of the blood-filled liver vasculature inferior vena cava (ivc) and the atria (at) in (B) and (C). In (D), the opaque volume model is coronally sectioned and the stapedial artery (sa) penetrating the developing stapes (st) is zoomed in on in the inlay to the top. The bottom inlay provides the aortic valve as detailed as it appears in the coronal 2D resection used as a sectioning plane. (E) shows a sagittally sectioned semitransparent volume model from lateral, integrating surface models of the urogenital tract. Choroid plexus (cp) and commissural fibres (cf) are detailed in the zoom-in displayed as an inlay to the top right. The bottom inlay shows a cranial and oblique view of the surface models of the ovaries (violet), ureter, urinary bladder and urethra (yellow), Müller duct (light blue) and Wolff duct (blue). (F-H). Chick embryo at developmental stage 18 according to Hamburger and Hamilton. Opaque volume model from the ventrolateral in (F) and (G) with a zoom-in on the virtually sectioned heart tube (ht) in (G). (H) shows the virtual 2D resection of the cutting plane in (G). ve, ventricles; li, liver; hb, hindbrain; co, cochlea; sv, semilunar valves; rlu, right lung; llu, left lung; te, telencephalon; di, diencephalon; sc, spinal chord; ns, nasal septum; to, tongue; la, larynx; uv, umbilical vein; I, intestine; pa, pharyngeal arches; le, lens; ub, bud of upper limb; lb, bud of lower limb; ec, endocardial cushion. Scale bars: $500 \mu \mathrm{m}$. 
In the scope of this program, a standardised and ergonomic protocol for the comprehensive scoring of the morphologic phenotype of E14.5 embryos [38], a novel system for defining developmental substages of E14.5 mouse embryos [39], and reference data for the correct interpretation of phenotype abnormalities and for distinguishing variations from abnormalities [40] were created. Approximately 200 novel mouse phenotype (MP) terms were added to the MP ontology list as a result of HREM allowing for the detection of details that could not be detected with alternative imaging techniques. Numerous publications in highly ranked journals were produced based on HREM data generated in DMDD [38-48].

DMDD independent stand-alone studies researching genetic regulation of mouse development include the analysis of: normal and abnormal cardiovascular development [49-61]; the development of the limbs, cloaca and pancreas [42,62-64]; ciliopathies [65]; and the characterisation of cardiac defects in Down syndrome mouse models $[66,67]$. Despite its value for analysing such processes in embryos between embryonic day E8.5 and E14.5, when organogenesis is already finished, HREM also proved its value for analysing developmental processes in very early embryos immediately after implantation [68].

HREM has proved an excellent fit for pure descriptive but also metric analysis, which will have a great impact on researching the influence of biomechanical forces on prenatal tissue and organ formation and remodelling. Simple descriptive studies allowed, for example, the visualisation of pharyngeal arch artery development, proved the transitory existence of a 5th pharyngeal arch artery in the mouse and defined the dimensions of large arteries in mouse embryos bred on various genetic backgrounds [69-74]. Precise visualisation of septation and cardiac cushion, the outflow tract and valve development were used as a basis for learning the concepts underlying associated malformations [75-86]. Besides its importance for research, digital 3D models are of course eagerly anticipated teaching aids, as they can exemplify complex developmental remodelling processes.

Simple metric data were produced for defining the dimensions of the great intrathoracic arteries of embryos bred on various genetic backgrounds. However, based on HREM data, more sophisticated models could be calculated, which could mathematically define the description of the heart looping process [52] or use 3D fractal analysis for defining the complexity of trabeculation during ventricular development of the heart [87-89].

\subsubsection{Chick Embryos}

Chick embryos of very early to late developmental stages were already examined, as shown in Figure 2. Embryos of the blastoderm stage $[90,91]$ were used for researching the effect that the storage of eggs has on embryonic development and viability. Embryos of late developmental stages have been successfully used for analysing the effect of hemodynamic alterations on the topology and remodelling of the cardiac outflow [72], and for producing metric definition of the dimensions of the great intrathoracic arteries to serve as reference data for such studies [73]. In addition, HREM analysis of an embryo with cephalothoracopagus malformation was successfully conducted, which permitted the formulation of a novel concept explaining the genesis of this abnormality [92].

\subsubsection{Embryos/Fetuses of Other Species}

HREM is not restricted to research mouse and chick embryos. It also has been shown to work on a broad variety of embryos of biomedical models. This includes quail and Xenopus embryos, where the proof of principle was published $[17,28]$, but also includes the zebrafish, for which HREM was shown to fit for visualisation and mathematical characterisation of complex developmental processes, such as dentation and cardiac jogging $[17,93]$.

Yet, HREM is not restricted to small biomedical models. 3D visualisation of voluminous fetal material is also possible. In particular, joint development was visualised in horse fetuses [94]. Furthermore, the potential of HREM to analyse the heart morphology of human fetal hearts in the first trimester has been shown $[95,96]$. Also, other (data not yet published) fetal materials fit as well 
for HREM imaging, but due to restricted availability of human embryos for morphological studies, collecting such materials is rather problematic and limited to highly specific scientific projects.

\subsection{HREM for Visualising Adult Material}

Though originally developed for imaging embryonic samples, protocols are already available for preparing biopsy material from adult individuals of various species for HREM imaging, as shown in Figure 3. Examples are materials stemming from rodents, zebrafish, turquoise killfish, ferrets and the fruit fly, for which there are preliminary data, but no publications yet exist.
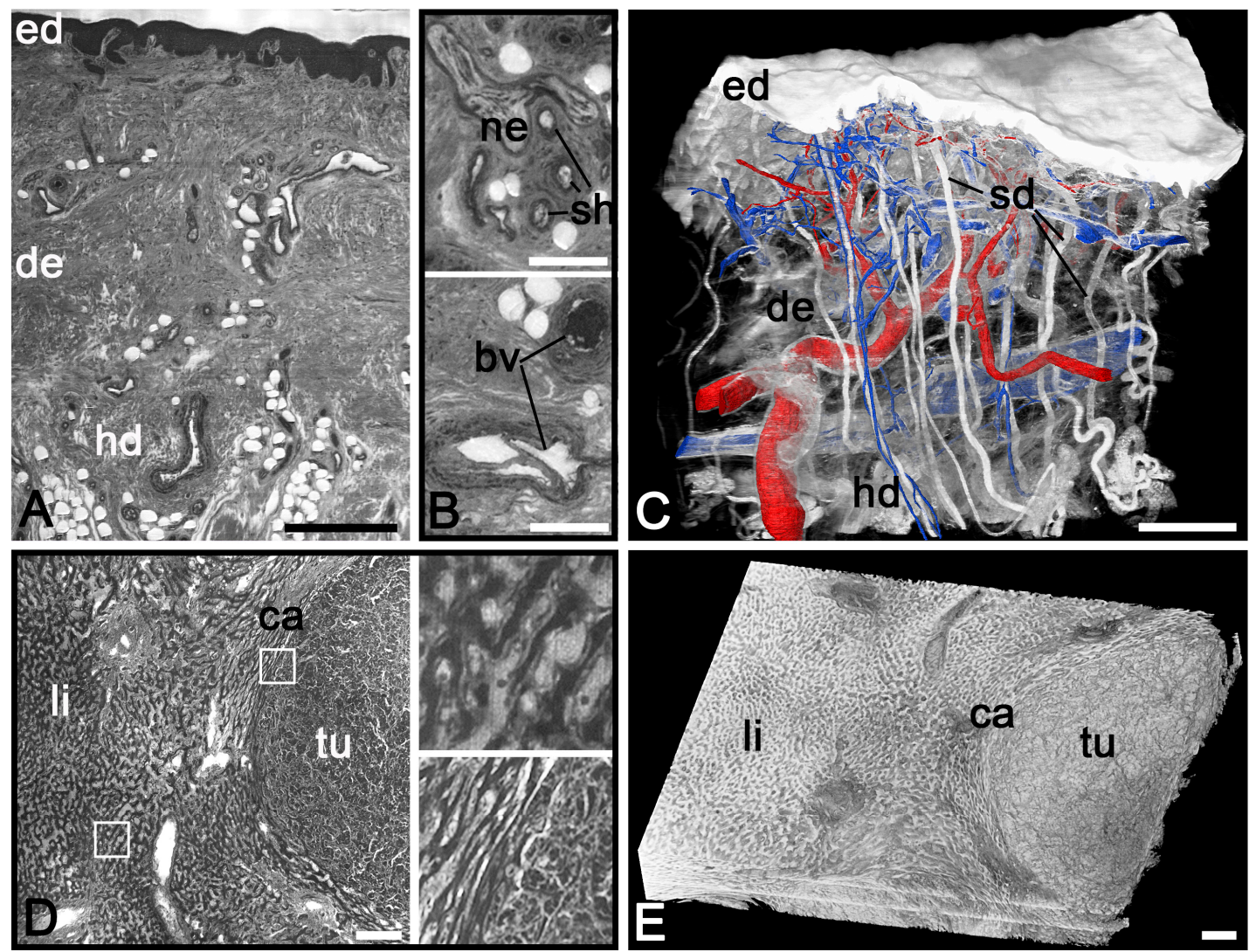

Figure 3. HREM data created from material harvested from adult human (A-C) skin biopsies. Virtual resection perpendicular to the original HREM section plane (A). (B) shows details from the original HREM sections to demonstrate HREM's ability to visualize small dermal nerves (ne) and a Suquet-Hoyer canal (sh) in the top image and small dermal blood vessels (bv) in the bottom image. (C) shows a semitransparent 3D volume model of the sample combined with surface models of the lumina of the dermal arteries (red) and veins (blue). (D,E) show metastatic material (tu) in a liver (li) biopsy. Original 2D HREM section in (D). Boxed areas are zoomed-in views provided as inlays to the right. (E) shows a 3D volume model. ed, epidermis; de, dermis; hd, hypodermis; ca, fibrous tumour capsule; sd, sweat duct. Scale bars $500 \mu \mathrm{m}$ in (A), (C), (D), (E); $150 \mu \mathrm{m}$ in (B).

Published data does exist for the pig and the mouse, in which vascularisation in wound healing was researched [97,98], and for humans. In humans, HREM was successfully employed to develop a novel concept for dermal vascularisation in thick $[99,100]$ and thin skin [101] and to analyse the topology of arteries and nerves in the auricle [102]. Besides this, it recently permitted the characterisation of plaques in the coronary arteries [103].

HREM could also show the structure of dermal matrix skin substitutes with and without seeded keratinocytes, and the effect of dermal matrix skin substitutes in combination with skin graft transplants on vascularisation in a porcine wound model. Recently, HREM was an integral part of a 
multimodal imaging pipeline for comprehensively characterising the vascularisation of murine tumour models [104].

\subsection{HREM for Other Organic Materials}

The materials primarily subjected to HREM imaging are sourced from animals. However, very recently, HREM expanded its application into the realm of plant sciences. More concretely, the morphology of wild-type and genetically altered tomato plants were visualised in order to study abnormal leaf axil patterning [105]. In pilot studies, the capacity of HREM for testing paper quality $[28,106]$ and the fibre arrangement and the formation of keratinocytes seeded on skin replacement material [107] were evaluated. These experiments demonstrated that HREM is not restricted to biomedical research, but has yet-unknown capacities to aid research in many other fields of modern science.

\section{Conclusions and Further Perspectives}

HREM was developed in 2006, and for about a decade, operated on self-assembled apparatuses. In 2015, a fully operable, all-inclusive HREM machine became commercially available under the trade name of 3D Optical HREM imaging (OHREM). This increased the number of projects using the HREM technique, which was illustrated by a quadruplication of publications based on HREM data over the last ten years, and it boosted the development of new protocols and technical advancements. However, HREM is still to be considered as a technique in its beginnings with great potential for refinement and improvement. As pilot data has shown, it has a yet-unexplored high potential for visualising a broad variety of organic materials in unmatched resolution and data quality.

\subsection{Stitching}

One of the strengths of HREM is its ability to image volumes of up to $6 \times 6 \times 12 \mathrm{~mm}^{3}$ in a numeric resolution of $3 \times 3 \times 3 \mu \mathrm{m}^{3}$. Increasing the numeric resolution is possible, but requires focusing on a smaller volume to be scanned [34,108]. First prototypes of HREM machines, which scan several images of the same block-surface and incorporate stitching algorithms for combining them, overcome these limitations and are already in use. It is to be expected that this promising approach will soon advance to become the HREM routine.

\subsection{Pipelines}

Even by using block scanning and stitching, the use of HREM is limited to exploring the microanatomy of specimens of a relatively small size. For large specimens, HREM imaging has to be combined with other imaging modalities to gain HREM detail in the context of overall specimen information. Since this is quite simple with techniques such $\mu$ MRI, the first imaging pipeline that includes HREM dates back to the very early phase of HREM imaging [51]. Large batches of embryos were scanned with high-throughput $\mu \mathrm{MRI}$ in moderate resolution. Interesting specimens or specimen parts were then identified, selected and subjected to HREM imaging for providing tissue detail. This approach was modified and expanded in the last years [109], and the first publications providing protocols and demonstrating the benefits of high complex multimodal, multiscale imaging pipelines integrating HREM with imaging modalities such as $\mu$ MRI, US, $\mu C T, O C T$, PAT and histopathology are already in preparation [104].

\subsection{Specific Stainings}

HREM data volumes comprise thousands of digital images, each resembling a greyscale image of a hematoxylin-eosine-stained histological section. Thus, HREM offers 3D information of morphological details of organic materials in a straightforward and simple way. Attempts to expand HREM to permit $3 \mathrm{D}$ visualisation of specifically labelled structures and molecular signals as well are as old as the HREM 
technique itself. Even the first publication included an example for visualising LacZ-stained tissues in mouse embryos and NBT/BCIP signals after whole-mount in situ hybridisation in zebrafish embryos [17]. However, despite these efforts, visualising specific stained tissues is still experimental and restricted to small specimens and specimens composed of loose and easy-to-penetrate tissues $[103,110,111]$. Protocols for late embryos and dense tissues are eagerly anticipated and will open new fields of applications for HREM. We are confident that with the growing community of HREM developers and users, solutions for this problem will be presented within the next few years.

Author Contributions: Conceptualization, S.H.G. and W.J.W.; writing—original draft preparation, S.H.G. and W.J.W.; writing—review and editing, S.H.G. and W.J.W.; visualization, S.H.G. and W.J.W.; supervision, W.J.W.

Funding: This research received no external funding.

Acknowledgments: The authors thank Barbara Maurer-Gesek and all the participants in the DMDD program.

Conflicts of Interest: The authors declare no conflict of interest.

\section{References}

1. Annan, A. GPR-History, trends, and future developments. Subsurf. Sens. Technol. Appl. 2002, 3, 253-270. [CrossRef]

2. Nikolic, M.; Conrad, C.; Zhang, J.; Scarcelli, G. Noninvasive Imaging: Brillouin Confocal Microscopy. Adv. Exp. Med. Biol. 2018, 1092, 351-364. [CrossRef] [PubMed]

3. Yun, S.H.; Chernyak, D. Brillouin microscopy: Assessing ocular tissue biomechanics. Curr. Opin. Ophthalmol. 2018, 29, 299-305. [CrossRef] [PubMed]

4. Peix, A.; Mesquita, C.T.; Paez, D.; Pereira, C.C.; Felix, R.; Gutierrez, C.; Jaimovich, R.; Ianni, B.M.; Soares, J., Jr.; Olaya, P.; et al. Nuclear medicine in the management of patients with heart failure: Guidance from an expert panel of the International Atomic Energy Agency (IAEA). Nucl. Med. Commun. 2014, 35, 818-823. [CrossRef] [PubMed]

5. Wei, W.; Ehlerding, E.B.; Lan, X.; Luo, Q.; Cai, W. PET and SPECT imaging of melanoma: The state of the art. Eur. J. Nucl. Med. and Mol. Imaging 2018, 45, 132-150. [CrossRef] [PubMed]

6. Hutchinson, J.C.; Shelmerdine, S.C.; Simcock, I.C.; Sebire, N.J.; Arthurs, O.J. Early clinical applications for imaging at microscopic detail: Microfocus computed tomography (micro-CT). Br. J. Radiol. 2017, 90, 20170113. [CrossRef] [PubMed]

7. Spaide, R.F.; Fujimoto, J.G.; Waheed, N.K.; Sadda, S.R.; Staurenghi, G. Optical coherence tomography angiography. Prog. Retin Eye Res. 2018, 64, 1-55. [CrossRef]

8. Levine, A.; Wang, K.; Markowitz, O. Optical Coherence Tomography in the Diagnosis of Skin Cancer. Dermatol. Clin. 2017, 35, 465-488. [CrossRef]

9. Liu, M.; Maurer, B.; Hermann, B.; Zabihian, B.; Sandrian, M.G.; Unterhuber, A.; Baumann, B.; Zhang, E.Z.; Beard, P.C.; Weninger, W.J.; et al. Dual modality optical coherence and whole-body photoacoustic tomography imaging of chick embryos in multiple development stages. Biomed. Opt. Express 2014, 5, 3150-3159. [CrossRef]

10. Cleary, J.O.; Modat, M.; Norris, F.C.; Price, A.N.; Jayakody, S.A.; Martinez-Barbera, J.P.; Greene, N.D.E.; Hawkes, D.J.; Ordidge, R.J.; Scambler, P.J.; et al. Magnetic resonance virtual histology for embryos: 3D atlases for automated high-throughput phenotyping. Neuroimage 2011, 54, 769-778. [CrossRef]

11. Zamyadi, M.; Baghdadi, L.; Lerch, J.P.; Bhattacharya, S.; Schneider, J.E.; Henkelman, R.M.; Sled, J.G. Mouse embryonic phenotyping by morphometric analysis of MR images. Physiol. Genom. 2010, 42, 89-95. [CrossRef] [PubMed]

12. Stylianou, A.; Kontomaris, S.V.; Grant, C.; Alexandratou, E. Atomic Force Microscopy on Biological Materials Related to Pathological Conditions. Scanning 2019, 2019, 8452851. [CrossRef] [PubMed]

13. Dufrene, Y.F.; Ando, T.; Garcia, R.; Alsteens, D.; Martinez-Martin, D.; Engel, A.; Gerber, C.; Muller, D.J. Imaging modes of atomic force microscopy for application in molecular and cell biology. Nat. Nanotechnol. 2017, 12, 295-307. [CrossRef] [PubMed]

14. Ban, S.; Cho, N.H.; Min, E.; Bae, J.K.; Ahn, Y.; Shin, S.; Park, S.A.; Lee, Y.; Jung, W. Label-free optical projection tomography for quantitative 3D anatomy of mouse embryo. J. Biophotonics 2019, 12, e201800481. [CrossRef] [PubMed] 
15. Sharpe, J. Optical projection tomography as a new tool for studying embryo anatomy. J. Anat. 2003, 202, 175-181. [CrossRef] [PubMed]

16. Sharpe, J.; Ahlgren, U.; Perry, P.; Hill, B.; Ross, A.; Hecksher-Sorensen, J.; Baldock, R.; Davidson, D. Optical projection tomography as a tool for 3D microscopy and gene expression studies. Science 2002, 296, 541-545. [CrossRef] [PubMed]

17. Weninger, W.J.; Geyer, S.H.; Mohun, T.J.; Rasskin-Gutman, D.; Matsui, T.; Ribeiro, I.; Costa Lda, F.; Izpisua-Belmonte, J.C.; Muller, G.B. High-resolution episcopic microscopy: A rapid technique for high detailed 3D analysis of gene activity in the context of tissue architecture and morphology. Anat. Embryol. 2006, 211, 213-221. [CrossRef] [PubMed]

18. Denk, W.; Horstmann, H. Serial block-face scanning electron microscopy to reconstruct three-dimensional tissue nanostructure. PLoS Biol. 2004, 2, e329. [CrossRef]

19. Odgaard, A. Quantification of Connectivity in Cancellous Bone, with Special Emphasis on 3-D Reconstructions. Bone 1993, 14, 173-182. [CrossRef]

20. Odgaard, A.; Andersen, K.; Melsen, F.; Gundersen, H.J. A direct method for fast three-dimensional serial reconstruction. J. Microsc. 1990, 159, 335-342. [CrossRef]

21. Odgaard, A.; Andersen, K.; Ullerup, R.; Frich, L.H.; Melsen, F. Three-dimensional reconstruction of entire vertebral bodies. Bone 1994, 15, 335-342. [CrossRef]

22. Weninger, W.J.; Meng, S.; Streicher, J.; Müller, G.B. A new episcopic method for rapid 3-D reconstruction: Applications in anatomy and embryology. Anat. Embryol. 1998, 197, 341-348. [CrossRef]

23. Gerneke, D.A.; Sands, G.B.; Ganesalingam, R.; Joshi, P.; Caldwell, B.J.; Smaill, B.H.; Legrice, I.J. Surface imaging microscopy using an ultramiller for large volume 3D reconstruction of wax- and resin-embedded tissues. Microsc. Res. Tech. 2007, 70, 886-894. [CrossRef] [PubMed]

24. Ewald, A.J.; McBride, H.; Reddington, M.; Fraser, S.E.; Kerschmann, R. Surface imaging microscopy, an automated method for visualizing whole embryo samples in three dimensions at high resolution. Dev. Dyn. 2002, 225, 369-375. [CrossRef] [PubMed]

25. Spaan, J.A.; ter Wee, R.; van Teeffelen, J.W.; Streekstra, G.; Siebes, M.; Kolyva, C.; Vink, H.; Fokkema, D.S.; VanBavel, E. Visualisation of intramural coronary vasculature by an imaging cryomicrotome suggests compartmentalisation of myocardial perfusion areas. Med. Biol. Eng. Comput. 2005, 43, 431-435. [CrossRef] [PubMed]

26. Sivaguru, M.; Fried, G.A.; Miller, C.A.; Fouke, B.W. Multimodal optical microscopy methods reveal polyp tissue morphology and structure in Caribbean reef building corals. J. Vis. Exp. 2014, 91, e51824. [CrossRef] [PubMed]

27. Weninger, W.J.; Mohun, T. Phenotyping transgenic embryos: A rapid 3-D screening method based on episcopic fluorescence image capturing. Nat. Genet. 2002, 30, 59-65. [CrossRef]

28. Geyer, S.H.; Maurer-Gesek, B.; Reissig, L.F.; Weninger, W.J. High-resolution Episcopic Microscopy (HREM) - Simple and Robust Protocols for Processing and Visualizing Organic Materials. J. Vis. Exp. 2017, 125, e56071. [CrossRef]

29. Mohun, T.J.; Weninger, W.J. Generation of volume data by episcopic three-dimensional imaging of embryos. Cold Spring Harb. Protoc. 2012, 2012, 681-682. [CrossRef]

30. Mohun, T.J.; Weninger, W.J. Embedding embryos for high-resolution episcopic microscopy (HREM). Cold Spring Harb. Protoc. 2012, 2012, 678-680. [CrossRef]

31. Mohun, T.J.; Weninger, W.J. Episcopic three-dimensional imaging of embryos. Cold Spring Harb. Protoc. 2012, 2012, 641-646. [CrossRef] [PubMed]

32. Zhang, H.; Huang, J.; Liu, X.; Zhu, P.; Li, Z.; Li, X. Rapid Acquisition of 3D Images Using High-resolution Episcopic Microscopy. J. Vis. Exp. 2016, 117, e54625. [CrossRef]

33. Weninger, W.J.; Maurer-Gesek, B.; Reissig, L.F.; Prin, F.; Wilson, R.; Galli, A.; Adams, D.J.; White, J.K.; Mohun, T.J.; Geyer, S.H. Visualising the Cardiovascular System of Embryos of Biomedical Model Organisms with High Resolution Episcopic Microscopy (HREM). J. Cardiovasc. Dev. Dis. 2018, 5, 58. [CrossRef] [PubMed] 
34. Geyer, S.H.; Mohun, T.J.; Weninger, W.J. Visualizing vertebrate embryos with episcopic 3D imaging techniques. Sci. World J. 2009, 9, 1423-1437. [CrossRef] [PubMed]

35. Mohun, T.J.; Weninger, W.J. Imaging heart development using high-resolution episcopic microscopy. Curr. Opin Genet. Dev. 2011, 21, 573-578. [CrossRef] [PubMed]

36. Mohun, T.; Weninger, W.J.; Bhattacharya, S. Imaging Cardiac Developmental Malformations in the Mouse Embryo. In Heart Development and Regeneration; Rosenthal, N., Harvey, R.P., Eds.; Academic Press: London, UK, 2010; pp. 779-791.

37. Mohun, T.; Adams, D.J.; Baldock, R.; Bhattacharya, S.; Copp, A.J.; Hemberger, M.; Houart, C.; Hurles, M.E.; Robertson, E.; Smith, J.C.; et al. Deciphering the Mechanisms of Developmental Disorders (DMDD): A new programme for phenotyping embryonic lethal mice. Dis. Model. Mech. 2013, 6, 562-566. [CrossRef] [PubMed]

38. Weninger, W.J.; Geyer, S.H.; Martineau, A.; Galli, A.; Adams, D.J.; Wilson, R.; Mohun, T.J. Phenotyping structural abnormalities in mouse embryos using high-resolution episcopic microscopy. Dis. Model. Mech. 2014, 7, 1143-1152. [CrossRef] [PubMed]

39. Geyer, S.H.; Reissig, L.; Rose, J.; Wilson, R.; Prin, F.; Szumska, D.; Ramirez-Solis, R.; Tudor, C.; White, J.; Mohun, T.J.; et al. A staging system for correct phenotype interpretation of mouse embryos harvested on embryonic day 14 (E14.5). J. Anat. 2017, 230, 710-719. [CrossRef]

40. Geyer, S.H.; Reissig, L.F.; Husemann, M.; Hofle, C.; Wilson, R.; Prin, F.; Szumska, D.; Galli, A.; Adams, D.J.; White, J.; et al. Morphology, topology and dimensions of the heart and arteries of genetically normal and mutant mouse embryos at stages S21-S23. J. Anat. 2017, 231, 600-614. [CrossRef]

41. Collins, J.E.; White, R.J.; Staudt, N.; Sealy, I.M.; Packham, I.; Wali, N.; Tudor, C.; Mazzeo, C.; Green, A.; Siragher, E.; et al. Common and distinct transcriptional signatures of mammalian embryonic lethality. Nat. Commun. 2019, 10, 2792. [CrossRef]

42. De Franco, E.; Watson, R.A.; Weninger, W.J.; Wong, C.C.; Flanagan, S.E.; Caswell, R.; Green, A.; Tudor, C.; Lelliott, C.J.; Geyer, S.H.; et al. A Specific CNOT1 Mutation Results in a Novel Syndrome of Pancreatic Agenesis and Holoprosencephaly through Impaired Pancreatic and Neurological Development. Am. J. Hum. Genet. 2019, 104, 985-989. [CrossRef] [PubMed]

43. Henkelman, R.M.; Friedel, M.; Lerch, J.P.; Wilson, R.; Mohun, T. Comparing homologous microscopic sections from multiple embryos using HREM. Dev. Biol. 2016, 415, 1. [CrossRef] [PubMed]

44. Perez-Garcia, V.; Fineberg, E.; Wilson, R.; Murray, A.; Mazzeo, C.I.; Tudor, C.; Sienerth, A.; White, J.K.; Tuck, E.; Ryder, E.J.; et al. Placentation defects are highly prevalent in embryonic lethal mouse mutants. Nature 2018, 555, 463-468. [CrossRef]

45. Reissig, L.F.; Herdina, A.N.; Rose, J.; Maurer-Gesek, B.; Lane, J.L.; Prin, F.; Wilson, R.; Hardman, E.; Galli, A.; Tudor, C.; et al. The Col4a2(em1(IMPC)Wtsi) mouse line: Lessons from the Deciphering the Mechanisms of Developmental Disorders program. Biol. Open 2019, 8, bio042895. [CrossRef] [PubMed]

46. Wilson, R.; Geyer, S.H.; Reissig, L.; Rose, J.; Szumska, D.; Hardman, E.; Prin, F.; McGuire, C.; Ramirez-Solis, R.; White, J.; et al. Highly variable penetrance of abnormal phenotypes in embryonic lethal knockout mice. Wellcome Open Res. 2016, 1, 1. [CrossRef] [PubMed]

47. Wilson, R.; McGuire, C.; Mohun, T.; Project, D. Deciphering the mechanisms of developmental disorders: Phenotype analysis of embryos from mutant mouse lines. Nucleic Acids Res. 2016, 44, D855-D861. [CrossRef] [PubMed]

48. Dickinson, M.E.; Flenniken, A.M.; Ji, X.; Teboul, L.; Wong, M.D.; White, J.K.; Meehan, T.F.; Weninger, W.J.; Westerberg, H.; Adissu, H.; et al. High-throughput discovery of novel developmental phenotypes. Nature 2016, 537, 508-514. [CrossRef]

49. Notari, M.; Hu, Y.; Sutendra, G.; Dedeic, Z.; Lu, M.; Dupays, L.; Yavari, A.; Carr, C.A.; Zhong, S.; Opel, A.; et al. iASPP, a previously unidentified regulator of desmosomes, prevents arrhythmogenic right ventricular cardiomyopathy (ARVC)-induced sudden death. Proc. Natl. Acad. Sci. USA 2015, 112, E973-E981. [CrossRef]

50. Zhou, Z.; Wang, J.; Guo, C.; Chang, W.; Zhuang, J.; Zhu, P.; Li, X. Temporally Distinct Six2-Positive Second Heart Field Progenitors Regulate Mammalian Heart Development and Disease. Cell Rep. 2017, 18, 1019-1032. [CrossRef]

51. Pieles, G.; Geyer, S.H.; Szumska, D.; Schneider, J.; Neubauer, S.; Clarke, K.; Dorfmeister, K.; Franklyn, A.; Brown, S.D.; Bhattacharya, S.; et al. microMRI-HREM pipeline for high-throughput, high-resolution phenotyping of murine embryos. J. Anat. 2007, 211, 132-137. [CrossRef] 
52. Le Garrec, J.F.; Dominguez, J.N.; Desgrange, A.; Ivanovitch, K.D.; Raphael, E.; Bangham, J.A.; Torres, M.; Coen, E.; Mohun, T.J.; Meilhac, S.M. A predictive model of asymmetric morphogenesis from 3D reconstructions of mouse heart looping dynamics. Elife 2017, 6, e28951. [CrossRef] [PubMed]

53. Bailey, K.E.; MacGowan, G.A.; Tual-Chalot, S.; Phillips, L.; Mohun, T.J.; Henderson, D.J.; Arthur, H.M.; Bamforth, S.D.; Phillips, H.M. Disruption of embryonic ROCK signaling reproduces the sarcomeric phenotype of hypertrophic cardiomyopathy. JCI Insight 2019, 4, e125172. [CrossRef] [PubMed]

54. Dupays, L.; Shang, C.; Wilson, R.; Kotecha, S.; Wood, S.; Towers, N.; Mohun, T. Sequential Binding of MEIS1 and NKX2-5 on the Popdc2 Gene: A Mechanism for Spatiotemporal Regulation of Enhancers during Cardiogenesis. Cell Rep. 2015, 13, 183-195. [CrossRef] [PubMed]

55. Dupays, L.; Towers, N.; Wood, S.; David, A.; Stuckey, D.J.; Mohun, T. Furin, a transcriptional target of NKX2-5, has an essential role in heart development and function. PLoS ONE 2019, 14, e0212992. [CrossRef] [PubMed]

56. Ivins, S.; Chappell, J.; Vernay, B.; Suntharalingham, J.; Martineau, A.; Mohun, T.J.; Scambler, P.J. The CXCL12/CXCR4 Axis Plays a Critical Role in Coronary Artery Development. Dev. Cell 2015, 33, 455-468. [CrossRef] [PubMed]

57. Zak, J.; Vives, V.; Szumska, D.; Vernet, A.; Schneider, J.E.; Miller, P.; Slee, E.A.; Joss, S.; Lacassie, Y.; Chen, E.; et al. ASPP2 deficiency causes features of 1q41q42 microdeletion syndrome. Cell Death Differ. 2016, 23, 1973-1984. [CrossRef]

58. Garcia-Canadilla, P.; Cook, A.C.; Mohun, T.J.; Oji, O.; Schlossarek, S.; Carrier, L.; McKenna, W.J.; Moon, J.C.; Captur, G. Myoarchitectural disarray of hypertrophic cardiomyopathy begins pre-birth. J. Anat. 2019, in press. [CrossRef]

59. Lescroart, F.; Mohun, T.; Meilhac, S.M.; Bennett, M.; Buckingham, M. Lineage tree for the venous pole of the heart: Clonal analysis clarifies controversial genealogy based on genetic tracing. Circ. Res. 2012, 111, 1313-1322. [CrossRef]

60. Breckenridge, R.A.; Piotrowska, I.; Ng, K.E.; Ragan, T.J.; West, J.A.; Kotecha, S.; Towers, N.; Bennett, M.; Kienesberger, P.C.; Smolenski, R.T.; et al. Hypoxic regulation of hand1 controls the fetal-neonatal switch in cardiac metabolism. PLoS Biol. 2013, 11, e1001666. [CrossRef]

61. Rana, M.S.; Theveniau-Ruissy, M.; De Bono, C.; Mesbah, K.; Francou, A.; Rammah, M.; Dominguez, J.N.; Roux, M.; Laforest, B.; Anderson, R.H.; et al. Tbx1 coordinates addition of posterior second heart field progenitor cells to the arterial and venous poles of the heart. Circ. Res. 2014, 115, 790-799. [CrossRef]

62. Huang, Y.C.; Chen, F.; Li, X. Clarification of mammalian cloacal morphogenesis using high-resolution episcopic microscopy. Dev. Biol. 2016, 409, 106-113. [CrossRef] [PubMed]

63. Delaurier, A.; Burton, N.; Bennett, M.; Baldock, R.; Davidson, D.; Mohun, T.J.; Logan, M.P. The Mouse Limb Anatomy Atlas: An interactive 3D tool for studying embryonic limb patterning. BMC Dev. Biol. 2008, 8, 83. [CrossRef] [PubMed]

64. Hasson, P.; DeLaurier, A.; Bennett, M.; Grigorieva, E.; Naiche, L.A.; Papaioannou, V.E.; Mohun, T.J.; Logan, M.P. Tbx4 and tbx5 acting in connective tissue are required for limb muscle and tendon patterning. Dev. Cell 2010, 18, 148-156. [CrossRef] [PubMed]

65. Kim, Y.J.; Osborn, D.P.; Lee, J.Y.; Araki, M.; Araki, K.; Mohun, T.; Kansakoski, J.; Brandstack, N.; Kim, H.T.; Miralles, F.; et al. WDR11-mediated Hedgehog signalling defects underlie a new ciliopathy related to Kallmann syndrome. EMBO Rep. 2018, 19, 269-289. [CrossRef]

66. Dunlevy, L.; Bennett, M.; Slender, A.; Lana-Elola, E.; Tybulewicz, V.L.; Fisher, E.M.; Mohun, T. Down's syndrome-like cardiac developmental defects in embryos of the transchromosomic Tc1 mouse. Cardiovasc. Res. 2010, 88, 287-295. [CrossRef] [PubMed]

67. Lana-Elola, E.; Watson-Scales, S.; Slender, A.; Gibbins, D.; Martineau, A.; Douglas, C.; Mohun, T.; Fisher, E.M.; Tybulewicz, V. Genetic dissection of Down syndrome-associated congenital heart defects using a new mouse mapping panel. Elife 2016, 5, e11614. [CrossRef] [PubMed]

68. Gershon, E.; Hadas, R.; Elbaz, M.; Booker, E.; Muchnik, M.; Kleinjan-Elazary, A.; Karasenti, S.; Genin, O.; Cinnamon, Y.; Gray, P.C. Identification of Trophectoderm-Derived Cripto as an Essential Mediator of Embryo Implantation. Endocrinology 2018, 159, 1793-1807. [CrossRef] [PubMed] 
69. Bamforth, S.D.; Chaudhry, B.; Bennett, M.; Wilson, R.; Mohun, T.J.; Van Mierop, L.H.; Henderson, D.J.; Anderson, R.H. Clarification of the identity of the mammalian fifth pharyngeal arch artery. Clin. Anat. 2013, 26, 173-182. [CrossRef] [PubMed]

70. Geyer, S.H.; Maurer, B.; Potz, L.; Singh, J.; Weninger, W.J. High-resolution episcopic microscopy data-based measurements of the arteries of mouse embryos: Evaluation of significance and reproducibility under routine conditions. Cells Tissues Organs 2012, 195, 524-534. [CrossRef] [PubMed]

71. Geyer, S.H.; Weninger, W.J. Metric characterization of the aortic arch of early mouse fetuses and of a fetus featuring a double lumen aortic arch malformation. Ann. Anat. 2013, 195, 175-182. [CrossRef] [PubMed]

72. Maurer-Gesek, B. Malformations of the Great Intrathoracic Arteries caused by Hemodynamic Alterations in Chick Embryos. Ph.D. Thesis, Medical University of Vienna, Vienna, Austria, 2016.

73. Weninger, W.J.; Maurer, B.; Zendron, B.; Dorfmeister, K.; Geyer, S.H. Measurements of the diameters of the great arteries and semi-lunar valves of chick and mouse embryos. J. Microsc. 2009, 234, 173-190. [CrossRef] [PubMed]

74. Geyer, S.H.; Weninger, W.J. Some mice feature 5th pharyngeal arch arteries and double-lumen aortic arch malformations. Cells Tissues Organs 2012, 196, 90-98. [CrossRef] [PubMed]

75. Aiello, V.D.; Spicer, D.E.; Anderson, R.H.; Brown, N.A.; Mohun, T.J. The independence of the infundibular building blocks in the setting of double-outlet right ventricle. Cardiol. Young 2017, 27, 825-836. [CrossRef] [PubMed]

76. Anderson, R.H.; Brown, N.A.; Mohun, T.J. Insights regarding the normal and abnormal formation of the atrial and ventricular septal structures. Clin. Anat. 2016, 29, 290-304. [CrossRef] [PubMed]

77. Anderson, R.H.; Chaudhry, B.; Mohun, T.J.; Bamforth, S.D.; Hoyland, D.; Phillips, H.M.; Webb, S.; Moorman, A.F.; Brown, N.A.; Henderson, D.J. Normal and abnormal development of the intrapericardial arterial trunks in humans and mice. Cardiovasc. Res. 2012, 95, 108-115. [CrossRef] [PubMed]

78. Anderson, R.H.; Jensen, B.; Mohun, T.J.; Petersen, S.E.; Aung, N.; Zemrak, F.; Planken, R.N.; MacIver, D.H. Key Questions Relating to Left Ventricular Noncompaction Cardiomyopathy: Is the Emperor Still Wearing Any Clothes? Can. J. Cardiol. 2017, 33, 747-757. [CrossRef]

79. Anderson, R.H.; Mohun, T.J.; Brown, N.A. Clarifying the morphology of the ostium primum defect. J. Anat. 2015, 226, 244-257. [CrossRef]

80. Anderson, R.H.; Mohun, T.J.; Sanchez-Quintana, D.; Mori, S.; Spicer, D.E.; Cheung, J.W.; Lerman, B.B. The anatomic substrates for outflow tract arrhythmias. Heart Rhythm 2019, 16, 290-297. [CrossRef]

81. Anderson, R.H.; Mori, S.; Spicer, D.E.; Brown, N.A.; Mohun, T.J. Development and Morphology of the Ventricular Outflow Tracts. World J. Pediatric Congenit. Heart Surg. 2016, 7, 561-577. [CrossRef]

82. Anderson, R.H.; Spicer, D.E.; Brown, N.A.; Mohun, T.J. The development of septation in the four-chambered heart. Anat. Rec. 2014, 297, 1414-1429. [CrossRef]

83. Anderson, R.H.; Spicer, D.E.; Mohun, T.J.; Hikspoors, J.; Lamers, W.H. Remodeling of the Embryonic Interventricular Communication in Regard to the Description and Classification of Ventricular Septal Defects. Anat. Rec. 2019, 302, 19-31. [CrossRef]

84. Sizarov, A.; Lamers, W.H.; Mohun, T.J.; Brown, N.A.; Anderson, R.H.; Moorman, A.F. Three-dimensional and molecular analysis of the arterial pole of the developing human heart. J. Anat. 2012, 220, 336-349. [CrossRef] [PubMed]

85. Spicer, D.E.; Bridgeman, J.M.; Brown, N.A.; Mohun, T.J.; Anderson, R.H. The anatomy and development of the cardiac valves. Cardiol. Young 2014, 24, 1008-1022. [CrossRef] [PubMed]

86. Tretter, J.T.; Steffensen, T.; Westover, T.; Anderson, R.H.; Spicer, D.E. Developmental considerations with regard to so-called absence of the leaflets of the arterial valves. Cardiol. Young 2017, 27, 302-311. [CrossRef] [PubMed]

87. Captur, G.; Ho, C.Y.; Schlossarek, S.; Kerwin, J.; Mirabel, M.; Wilson, R.; Rosmini, S.; Obianyo, C.; Reant, P.; Bassett, P.; et al. The embryological basis of subclinical hypertrophic cardiomyopathy. Sci. Rep. 2016, 6, 27714. [CrossRef] [PubMed]

88. Captur, G.; Wilson, R.; Bennett, M.F.; Luxan, G.; Nasis, A.; de la Pompa, J.L.; Moon, J.C.; Mohun, T.J. Morphogenesis of myocardial trabeculae in the mouse embryo. J. Anat. 2016, 229, 314-325. [CrossRef] [PubMed] 
89. Paun, B.; Bijnens, B.; Cook, A.C.; Mohun, T.J.; Butakoff, C. Quantification of the detailed cardiac left ventricular trabecular morphogenesis in the mouse embryo. Med. Image Anal. 2018, 49, 89-104. [CrossRef] [PubMed]

90. Pokhrel, N.; Ben-Tal Cohen, E.; Genin, O.; Sela-Donenfeld, D.; Cinnamon, Y. Cellular and morphological characterization of blastoderms from freshly laid broiler eggs. Poult. Sci. 2017, 96, 4399-4408. [CrossRef]

91. Pokhrel, N.; Cohen, E.B.; Genin, O.; Ruzal, M.; Sela-Donenfeld, D.; Cinnamon, Y. Effects of storage conditions on hatchability, embryonic survival and cytoarchitectural properties in broiler from young and old flocks. Poult. Sci. 2018, 97, 1429-1440. [CrossRef] [PubMed]

92. Maurer, B.; Geyer, S.H.; Weninger, W.J. A chick embryo with a yet unclassified type of cephalothoracopagus malformation and a hypothesis for explaining its genesis. Anat. Histol. Embryol. 2013, 42, 191-200. [CrossRef]

93. Bruneel, B.; Matha, M.; Paesen, R.; Ameloot, M.; Weninger, W.J.; Huysseune, A. Imaging the zebrafish dentition: From traditional approaches to emerging technologies. Zebrafish 2015, 12, 1-10. [CrossRef] [PubMed]

94. Jenner, F.; van Osch, G.J.; Weninger, W.; Geyer, S.; Stout, T.; van Weeren, R.; Brama, P. The embryogenesis of the equine femorotibial joint: The equine interzone. Equine Vet. J. 2015, 47, 620-622. [CrossRef] [PubMed]

95. Matsui, H.; Mohun, T.; Gardiner, H.M. Three-dimensional reconstruction imaging of the human foetal heart in the first trimester. Eur. Heart J. 2010, 31, 415. [CrossRef] [PubMed]

96. Gindes, L.; Matsui, H.; Achiron, R.; Mohun, T.; Ho, S.Y.; Gardiner, H. Comparison of ex-vivo high-resolution episcopic microscopy with in-vivo four-dimensional high-resolution transvaginal sonography of the first-trimester fetal heart. Ultrasound Obstet. Gynecol. 2012, 39, 196-202. [CrossRef] [PubMed]

97. Ertl, J.; Pichlsberger, M.; Tuca, A.C.; Wurzer, P.; Fuchs, J.; Geyer, S.H.; Maurer-Gesek, B.; Weninger, W.J.; Pfeiffer, D.; Bubalo, V.; et al. Comparative study of regenerative effects of mesenchymal stem cells derived from placental amnion, chorion and umbilical cord on dermal wounds. Placenta 2018, 65, 37-46. [CrossRef] [PubMed]

98. Wiedner, M.; Tinhofer, I.E.; Kamolz, L.P.; Seyedian Moghaddam, A.; Justich, I.; Liegl-Atzwanger, B.; Bubalo, V.; Weninger, W.J.; Lumenta, D.B. Simultaneous dermal matrix and autologous split-thickness skin graft transplantation in a porcine wound model: A three-dimensional histological analysis of revascularization. Wound Repair Regen. 2014, 22, 749-754. [CrossRef] [PubMed]

99. Geyer, S.H.; Nohammer, M.M.; Matha, M.; Reissig, L.; Tinhofer, I.E.; Weninger, W.J. High-resolution episcopic microscopy (HREM): A tool for visualizing skin biopsies. Microsc. Microanal. 2014, 20, 1356-1364. [CrossRef]

100. Geyer, S.H.; Nohammer, M.M.; Tinhofer, I.E.; Weninger, W.J. The dermal arteries of the human thumb pad. J. Anat. 2013, 223, 603-609. [CrossRef]

101. Tinhofer, I.E.; Zaussinger, M.; Geyer, S.H.; Meng, S.; Kamolz, L.P.; Tzou, C.H.; Weninger, W.J. The dermal arteries in the cutaneous angiosome of the descending genicular artery. J. Anat. 2018, 232, 979-986. [CrossRef]

102. Razlighi, B.D.; Kampusch, S.; Geyer, S.H.; Hoang Le, V.; Thurk, F.; Brenner, S.; Szeles, J.C.; Weninger, W.J.; Kaniusas, E. In-Silico Ear Model Based on Episcopic Images for Percutaneous Auricular Vagus Nerve Stimulation. In Proceedings of the 2018 EMF-Med 1st World Conference on Biomedical Applications of Electromagnetic Fields (EMF-Med), Split, Croatia, 10-13 September 2018.

103. Franck, G.; Even, G.; Gautier, A.; Salinas, M.; Loste, A.; Procopio, E.; Gaston, A.T.; Morvan, M.; Dupont, S.; Deschildre, C.; et al. Haemodynamic stress-induced breaches of the arterial intima trigger inflammation and drive atherogenesis. Eur. Heart J. 2019, 40, 928-937. [CrossRef]

104. Walter, A. Correlated Multimodal Imaging of Tumour Vasculature. (manuscript in preparation).

105. Izhaki, A.; Alvarez, J.P.; Cinnamon, Y.; Genin, O.; Liberman-Aloni, R.; Eyal, Y. The Tomato BLADE ON PETIOLE and TERMINATING FLOWER Regulate Leaf Axil Patterning Along the Proximal-Distal Axes. Front. Plant Sci. 2018, 9, 1126. [CrossRef]

106. Wiltsche, M.; Donoser, M.; Kritzinger, J.; Bauer, W. Automated serial sectioning applied to 3D paper structure analysis. J. Microsc. 2011, 242, 197-205. [CrossRef]

107. Geyer, S.H.; Tinhofer, I.E.; Lumenta, D.B.; Kamolz, L.P.; Branski, L.; Finnerty, C.C.; Herndon, D.N.; Weninger, W.J. High-resolution episcopic microscopy (HREM): A useful technique for research in wound care. Ann. Anat. 2015, 197, 3-10. [CrossRef]

108. Weninger, W.J.; Geyer, S.H. Episcopic 3D Imaging Methods: Tools for Researching Gene Function. Curr. Genom. 2008, 9, 282-289. [CrossRef] 
109. Desgrange, A.; Lokmer, J.; Marchiol, C.; Houyel, L.; Meilhac, S.M. Standardised imaging pipeline for phenotyping mouse laterality defects and associated heart malformations, at multiple scales and multiple stages. Dis. Model. Mech. 2019, 12, dmm038356. [CrossRef]

110. Weninger, W.J.; Kamolz, L.P.; Geyer, S.H. 3D Visualisation of Skin Substitutes. In Dermal Replacements in General, Burn, and Plastic Surgery; Kamolz, L.P., Lumenta, D.B., Eds.; Springer: Vienna, Austria, 2013.

111. Weninger, W.J.; Mohun, T.J. Three-dimensional analysis of molecular signals with episcopic imaging techniques. Methods Mol. Biol. 2007, 411, 35-46. [CrossRef]

(C) 2019 by the authors. Licensee MDPI, Basel, Switzerland. This article is an open access article distributed under the terms and conditions of the Creative Commons Attribution (CC BY) license (http://creativecommons.org/licenses/by/4.0/). 